the case, but the eggs remain in the nest in which they were originally placed by the parent Cuckoo, and are duly hatched by the foster-parent. That being so, the necessity for the law of nature which the Doctor wishes to establish falls to the ground. I do not like to put forward my own opinion against such great authorities as Dr. Baldamus and Professor Newton, but I think the inquiry now set on foot in this country by the publication in English of Dr. Baldamus' paper in Naumannia will be to show that Cuckoo's eggs do not in fact vary from each other more than those of many others, and that the resemblances to the eggs of many other species are not greater than sometimes arises in many ordinary cases.

Cecil Smith

\section{The Cloaca Maxima}

YOUR correspondent "Ignoramus" will find some account of the drainage of Rome in Pliny ("Hist. Nat." xxxvi. 15, 5. 24). He will also find further particulars in Livy (i. 38 ), and in Ulpian ("Dig." 43, tit. 23, 5. I).

History repeats itself. Just as the London sewers were origin ally natural brooks or artificial ditches by which the rainfall of the district was carried off, and into which it was penal, down to the year 1815 , to turn any "sewage" proper; so the Cloaca Maxima was built originally, in very early times (by Tarquinius Priscus, according to Livy), to carry off the rain-water from the Forum. Afterwards, however, all kinds of liquid refuse were allowed to find their way into it; and this seemed such a convenient way of getting rid of troublesome matter, that the whole city was eventually undermined by a network of sewers, including small pipes of wood and earthenware cornecting the houses with the main sewers. Whether "traps" were also used I am unable to say, but I think it very probable that some simple combination of trap and cess-pit, in masonry, was used to prevent an up-blast of foul gas into the atrium.

What became of the solid refuse I do not know, but from all that I can gather I imagine it must have been carted away periodically. I trust some of your readers may have compassion for our ignorance, and, by enlightening us on this point, complately restore to "Ignoramus" that peace of mind which he lost in early childhood.

I trust also that the days of river cloacal pollution, in this country at least, are numbered, and that the advances which other sciences have made in the last 2,000 years will at last make our engineers ashamed of their ignorant violation of what $I$ hope I may be allowed to call one of the laws of Nature.

\section{Hydro-carbon Colours}

CAN your readers inform me of any book in which I can get to know all that is known on the "Hydro-carbon colours, and their application to Art industry," or direct me to any sources where the information can be obtained?

Plymouth, December I8

\section{T. W. FRECKELTON}

\section{NOTES}

THE Fournal of Botany will pass into new management with the commencement of the year. The leading English botanists have promised their co-operation towards making it a complete record of the progress of botany at home and abroad during the month. It will in future be edited by Mr. W. H. Trimen, M.B., of the British Museum, author of "A Flora of Middlesex."

THE persistent decrease in the yield of our sea-fisheries has assumed a serious aspect, and urgently calls for systematic investigation at the hands of the Government. The usual machinery for such investigations, namely, a Royal Commission, could, however, hardly obtain the exact kind of information necessary for a determination of the probable cause of the mischief. Nothing short of the appointment of Inspectors of Sea Fisheries, with analogous functions to those discharged (with such beneficial results) by the Inspectors of Salmon Fisheries, can afford the opportunity for a thorough examination of the subject, and prepare the way for useful legislation. This course is ably advocated in the last number of Land and Water, and we feel it incumbent upon us strongly to second the recommendations of our contemporary on this point.
ThE Ethnographical Section of the Geographical Society of Berlin, which has existed in a more or less definite form for about three years, has just separated itself from the parent organism, and entered upon an independent career as the Society for Anthropology and Ethnology. The first ordinary meeting of the new society took place on the roth instant, when a paper was read by Professor Virchow on the North-German Pile-works. As compared with the great majority of such remains in Switzerland and South Germany, the pile-works of the North are not of very high antiquity. There is only one colony, that of Wismar, which belongs to the Stone period ; even the older forms of bronze are rarely met with. The mode of construction of the pile-works likewise indicates an advance on that employed in Switzerland. Professor Virchow is of opinion that some, at least, of the earth works found in certain districts are contemporary with the lake habitations : evidence on this interesting point is promised at some future time. That the pile-works, although of comparatively recent date, are really pre-historic, is indicated by the discovery of the remains of beaver and elk. The latter animal is not mentioned by the old chroniclers of Brandenburg and Pomerania; neither do we frnd mention of any lake-dwelling people in the ancient Scandinavian or Polish historians.

WE understand that steps are being taken to found an anthropolngical society in Hamburg, but no particulars have as yet reached us.

We extract the following from the last Weekly Bulletin (26th inst.) of the Scientific Association of France:- "The vine occupies in France almost $2,500,000$ hectares $(6,175,000$ acres $)$. This constitutes the one-and-twentieth part of the French territory, and the sixteenth part of its soil capable of cultivation. The gross produce amounts to more than $I, 500,000,000$ francs. This industry occupies six million men, women, and children, and nearly two million merchants, agents, traders, \&c. Sixty-nine departments cultivate the vine, from the Gironde, which reckons more than I 50,000 hectares $(370,500$ acres $)$, to the department of Ille-etVilaine, which only possesses 104 hectares ( 256 acres)."

THE commission appointed by the Impen Academy of Medicine in Paris to investigate the subject or vaccination has just concluded its labours by the presentation of its Report, which has been adopted.

Mr. J. Mrers, so well known for his researches in the Botany of South America, is about to publish the second and third volumes of his "Contributions to Botany," which will include a complete monograph of the Menispermacer, and of the South American species, of Ephedra, showing that this genus does not belong to the Gymnosperms or naked-seeded plants, as generally believed.

In a letter of the $\mathrm{r} 7 \mathrm{th}$ ultimo, addressed to the Astronomische Nachrichten, Dr. Oppolzer discusses the observations of a faint comet discovered by Pons in February 1808, and arrives at the conclusion that it is exceedingly probable that the comet referred to is identical with that named after Winnecke. Dr. Oppolzer is at present engaged in working out the observations of the latter comet, more especially in reference to its supposed identity with Comet II. of 1766 .

WE regret to learn from the recent report of the Miners' Association for Cornwall and Devonshire, that that useful body is in danger of being dissolved in consequence of the inadequate support it receives from the mining interest. The importance of combining scientific knowledge with practical experience, if we intend to maintain our present position in mining and metallurgy as against the highly-trained miners of other countries, is acknowledged by every competent person. Surely, then, when owners (he of mines and shareholders in mining companies learn that the Miners' Association not only discusses and publishes important scieritific papers of a practical character, but is at the present 